\title{
Endocrine Function with Aqueous Fruit Extract of Solanum macrocarpum Linn. In Albino Rats Chronically Administered Triton-X to Induce Hyperlipidemia
}

\author{
O. A. Sodipo ${ }^{* 1}$, F.I. Abdulrahman ${ }^{2}$, U.K. Sandabe ${ }^{3}$ and B. Wampana ${ }^{3}$ \\ ${ }^{1 *}$ Deaprtment of Clinical Pharmacology and Therapeutics, College of Medical Sciences, \\ University of Maiduguri, P.M.B. 1069, Maiduguri. \\ ${ }^{2}$ Department of Chemistry, Faculty of Science, University of Maiduguri \\ ${ }^{3}$ Department of Veterinary Physiology Pharmacology and Biochemistry, Faculty of Veterinary Medicine, \\ University of Maiduguri, P.M.B. 1069, Maiduguri.
}

\begin{abstract}
Studies were conducted on the effect of the aqueous fruit extract of Solanum macrocarpum Linn. in chronic triton-induced hyperlipidemic rats. The plant was Soxhlet-extracted with distilled water and the extract concentrated in vacuo with a yield of $15.34 \% \mathrm{w} / \mathrm{w}$. The extract was stored in a specimen bottle in a desiccator at room temperature until when required. The endocrine function parameters: thyroid hormones (thyroxine ie. $\mathrm{T}_{4}, 3,5,3^{\prime}$ triiodothyronine i.e. $\mathrm{T}_{3}$ and thyroid stimulating hormone ie. TSH), testosterone, $17 \beta$ - oestradiol and insulin were determined. The results showed that with increase in extract dose there was a significant $(\mathrm{p}<0.05)$ increase in TSH and $\mathrm{T}_{4}$ at $72 \mathrm{hrs}$ whilst there was no change for $\mathrm{T}_{3}(\mathrm{p}>0.05)$ throughout the period of study. Oestradiol levels increased significantly ( $\mathrm{p}<0.05)$ at $24 \mathrm{hrs}$ and $72 \mathrm{hrs}$ when compared to the negative control (Group one), but the levels of the oestradiol level in the negative control was however higher than that of the rats not administered the extract (positive control or Group two). The positive control had an oestradiol level of (15.00 \pm 4.24$)$ $\mathrm{pg} / \mathrm{ml},(12.00 \pm 1.49) \mathrm{pg} / \mathrm{ml}$ and $(13.50 \pm 2.54) \mathrm{pg} / \mathrm{ml}$ at $24 \mathrm{hrs}, 48 \mathrm{hrs}$ and $72 \mathrm{hrs}$ respectively whilst the values of the oestradiol in the negative control rats (group one) are $(36.50 \pm 2.12) \mathrm{pg} / \mathrm{ml},(20.00 \pm 4.24) \mathrm{pg} / \mathrm{mol}$ and $(24.50 \pm 2.12) \mathrm{pg} / \mathrm{mol}$ at $24 \mathrm{hrs}, 48$ hrs and $72 \mathrm{hrs}$ respectively. The increase in the testosterone level with increase in extract dose was significant $(\mathrm{p}<0.05)$ at 48 hrs whilst the insulin levels increased significantly $(\mathrm{p}<0.05)$ at $48 \mathrm{hrs}$ and $72 \mathrm{hrs}$ when compared to the negative control. The aqueous fruit extract of $S$. macrocarpum by increasing the level of the thyroid homones, testosterone, $17 \beta$ oestratdiol and insulin in hyperlipidemic rats in this study probably imply a lipid lowering effect.
\end{abstract}

Keywords: Solanum macrocarpum Linn, aqueous extract, triton-X endocrine function, chronic hyperlipidemic rats.

\section{INTRODUCTION}

The control of metabolism, growth and reproduction is mediated by a combination of neural and endocrine systems located in the hypothalamus and pituitary gland (Katzung, 2004). Some of the endocrine hormones are thyroid hormones (thyroxine ie. T4, triiodothyronine i.e. $\mathrm{T}_{3}$ and thyrotrophin ie. TSH), reproductive hormones (testosterone and oestrogens) and the pancreatic hormone, insulin (Anthony, 2003).

The thyroid gland consists of two types of cells, the follicular and parafollicular cells (Gali, 2007). The follicular cells are responsible for the production of thyroxine also called $3,5,3$, 5' tetraiodothyronine or $\mathrm{T}_{4}$ and $3,5,3^{\prime}$ triiodothyronine or $\mathrm{T}_{3}$ ). $\mathrm{T}_{4}$ can be considered a pro-hormone and $\mathrm{T}_{3}$ is produced by extrathyroidal deiodination of $\mathrm{T}_{4}$ by the Type 1 deiodinase enzyme. $\mathrm{T}_{4}$ is biologically inactive and must be converted to $\mathrm{T}_{3}$ before biological activity is exerted (Oppenheimer, 1972). Thus, it is not surprising that the thyroid produces $100 \%$ of circulating thyroxine $\left(\mathrm{T}_{4}\right)$ but only about (5-10\%) of circulating $\mathrm{T}_{3}$ (Gali, 2007).

Thyroid hormones are indispensable for growth, mental development and sexual maturation in mammals. Conversely, excess thyroid secretion leads to body wasting, nervousness, tachycardia, tremor and excess heat production. Thyroid hormone absence leads to mental and physical slowing, poor resistance to cold and in children, mental retardation and dwarfism (Braverman, 1996; Gali, 2007). Thyroid hormone is required for the normal functions of nearly all tissues, with major effect on oxygen consumption and metabolic rate (Oppenheimer et al.,1987). These hormones also stimulate protein, carbohydrate and lipid metabolism (Gali, 2007). 
Thyroid function is controlled by the thyroid stimulating hormone (TSH) or thryotrophin of the anterior pituitary (Jackson, 1982; Gali, 2007). Thyroid hormones increase the expression of LDL receptors on the hepatocytes and increase the activity of lipid lowering liver enzymes, resulting in a reduction in LDL (Ness and Lopez, 1995; Ness et al.,1998; Shin and Timothy, 2003; Gali, 2007). Thyroid hormones also increase the expression of apolipoprotein $A_{1}$, a major component of HDL (Taylor et al., 1996; Gali, 2007). $\mathrm{T}_{3}$ also regulates post-transcriptional editing of apolipoprotein mRA (Davidson et al., 1998). In addition, $T_{3}$ is important in hepatic degradation of cholesterol into bile acids by increasing the transcription of the ratelimiting enzyme in the process, the cholesterol - 7a-hydroxylase (Ness et al.,1990; Pandak et al.,1997; Gali, 2007). The above effect of the thyroid hormones could be beneficial in reducing the onset of atherosclerosis, if they were elicited without deleterious effects, particularly the cardiac effect (Dillman, 1990; Woeber, 1992; Gali, 2007).

Oestrogens are $\mathrm{C}_{18}$ steroids with aromatic configuration in the A ring. $17 \beta$ oestradiol, oestrone and oestradiol are the three naturally occurring oestrogens found in the matured female body (Katzung, 2004; Aliu, 2007). Oestrodiol is the most potent naturally occurring oestrogen. Besides human ovary, oestrogens are also secreted by the placenta and to a lesser extent by the adrenal cortex and the testis (Katzung, 2004). Oestrodiol levels have been shown to be decreased in patients with myocardial infarction (Odutola, 1992; Williamson et al.,1996). Oestrogens have also been shown to decrease low density lipoprotein cholesterol (LDL-C) by $5-10 \%$. This lipid effect accounts for $25-40 \%$ in the reduction of coronary heart disease after oetestrogen therapy (ANON, 2008). Oestrogens also give a favourable lipid profile ie. increase high density lipoprotein cholesterol (HDL-C), decrease low density lipoprotein cholesterol (LDL-C) and reduce in total cholesterol (Katzung, 2004) which in turn may contribute to retardation of atherosclerotic cardiovascular disease.

Insulin is produced by the $\beta$-cells of the islet of Langerhans in the pancreas. Absolute or relative lack of insulin leads to diabetes mellitus (Katzung, 2004). Diabetes mellitus is a group of metabolic and endocrine disorders characterized by chronic hyperglyaemia and eventual glycosuria. It is caused by the inability of tissues to carry out normal metabolism of carbohydrates, fats and protein. Insulin is a small protein with a molecular weight in humans of 5, 808. It contains 51 amino acids arranged in 2 chains (A and B) and linked by disulphide bridges. There are specie differences in the amino acids of both chains (Katzung, 2004). In diabetes mellitus, insufficiency or deficiency of insulin leads to decreased synthesis of protein, lipids and glycogen. Increased mobilization of fat from adipose tissue leads to increased levels of cholesterol, lipids, free fatty acids and triglycerides ie. hyperlipidaemia (Katzung, 2004; Aliu, 2007). Also there is decreased high density lipoprotein cholesterol (HDL-C) in diabetes mellitus patients (Cabezes et al.,1993; Syvanne and Taskinen, 1997; Sodipo, 2009). At this same time, there seems to be few studies relating diabetes to hyperlipidemia (Sjoholm, 1998a; Sodipo, 2009).

Testosterone is the most important androgen secreted by the testis. It is synthesized from cholesterol in the leydig cells (95\%) and only 5\% by the adrenal cortex. In men, approximately $8 \mathrm{mg}$ testosterone is produced daily (Katzung, 2004). Plasma levels of testosterone in males daily drops to approximately $0.6 \mu \mathrm{g} / \mathrm{dl}$ after 50 years. Testosterone is also present in the plasma of women and is approximately $0.03 \mu \mathrm{g} / \mathrm{dl}$ (i.e. about $1 / 20$ times less) and is derived from the ovaries, the adrenal cortex and the peripheral conversion of other hormones (Katzung, 2004). It is reduced in males with myocardial infarction (Wiliamson et al.,1996; Katzung, 2004). The active form of the enzyme is dihydrotestosterone and this is achieved using the enzyme 5 $\alpha$-reductase (Katzung 2004; Sodipo, 2009). Also testosterone has been found at lower levels with a high fat diet (Williamson et al.,1996. Sodipo, 2009) and this is of note because high fat diet may eventually lead to hyperlipidaemia. In other words, it may be possible for hyperlipidemia to lower testosterone level which in turn may probably facilitate myocardial infarction.

In the traditional North East Arid zone of Nigeria, the unripe fruit of S. macrocarpum (synonyms: S. macrocarpum L. sensu stricto and S. daysphyllum Schumach and Thonn) [Grubben and Denton, 2004] called "Gorongo" in Kanuri is known for its laxative, antihypertensive and hypolipideamic effects. Importantly, S. macrocarpum had been shown to display a wide spectrum of biological activities with experimental support for the empiric ethnopharmacological use of this plant in folk medicine (Sodipo et al., 2008a,b; 2009a; 2012a).

Recently, we have demonstrated hepatoprotective effects of aqueous fruit extract of S. macrocarpum in diet-induced hypercholesterolaemic rats (Sodipo et al., 2009b), acute and chronic triton-induced hyperlipidemic rats respectively (Sodipo et al.,2011b, 2012a). However, the mechanism of hypolipidemia had not been extensively studied. Sodipo et al., (2009c; 2011a, 2012a) observed a favourable lipid profile in diet-induced hypercholesterolaemic acute and chronic-triton-induced hyperlipidaemic rats administered with the aqueous fruit extract, the exact mechanism of cholesterol lowering and hypolipidemia was not known. Taking into account these data, we have conducted our research on endocrine function tests $\left(\mathrm{T}_{3}, \mathrm{~T}_{4}, \mathrm{TSH}, 17 \beta\right.$-oestradiol, testosterone, insulin) after oral administration of triton-X 100 (a non-ionic surfactant that 
interferes with uptake of lipids) for 90 days to induce chronic hyperlipidaemia/ atherosclerosis in rats in order to find out if the fruit of $S$. macrocarpum can indeed lower hyperlipidaemia, as an increase in endocrine hormones corresponds to a decrease in LDL - C and increase in HDL-C (Odutola 1992; Williamson et al, 1996; Katzung, 2004; Gali, 2007; ANON, 2008; Sodipo, 2009). Also a plausible mechanism of the hypolipideamic action of the plant, if there is any could probably be fashioned out. At the same time, we will also try to find out if the extract has the potential to reduce development of coronary heart disease and atherosclerosis as increase in thyroid hormones, oestrogen, testosterone and insulin have been shown to be beneficial and indicative of a lower risk of coronary heart diseases (Odutola, 1992; Wiliamson et al., 1996; Katzung, 2004; Gali, 2007; ANON 2008; Sodipo, 2009).

\section{MATERIALS AND METHODS}

\section{Plant collection and identification}

The plant material (Solanum macrocarpum Linn.) used in this study was obtained from Alau in Konduga Local Government, Borno State, Nigeria, between October and November, 2007. The plant was identified and authenticated by Prof. S.S. Sanusi of the Department of Biological Sciences, University of Maiduguri, Maiduguri, Nigeria. Specimen voucher No. 548 was deposited at the Research Laboratory of the Department of Chemistry.

\section{Extraction}

The fruit of $S$. macrocarpum with the calyx removed was air-dried and pulverized by grinding using pestle and mortar. The $2.2 \mathrm{~kg}$ of the ground fruit was subjected to exhaustive Soxhlet-extraction in distilled water at $100{ }^{\circ} \mathrm{C}$ to give the extract yield of $15.3 \%$ w/w (Mittal et al.,1981, Fernando et al.,1991; Lin et al.,1999). The resultant solution was concentrated in vacuo and it was stored in a specimen bottle and kept in a desiccators at room temperature until when required.

\section{Animals}

Thirty six (36) male albino rats of Wistar strain weighing 160-200g were used in this study. The animals were obtained from the Animal House Unit of the Department of Veterinary Physiology, Pharmacology and Biochemistry, University of Maiduguri. They were housed under standard laboratory condition in plastic cages. They were fed commercial growers' mash feed (ECWA, Feeds, Jos, Nigeria) and water was provided ad libitum. All the animals were handled according to the International Guiding Principles for Biomedical Research Involving Animals (CIOMS, 1985) as certified by the Animal Ethics Committee of the Faculty of Veterinary Medicine, University of Maiduguri (Approved on October $15^{\text {th }} 2008$ at its $12^{\text {th }}$ Ethical Committee meeting).

\section{Administration of triton and extract}

Thirty (30) albino rats were made hyperlipidemic by feeding them orally (p.o) for 90 days with normal feed diet and triton-X (Sigma Chemical Co. St. Louis, M.O. USA) at a dose of $400 \mathrm{mg} / \mathrm{kg}$ in saline suspension from the stock concentration of 535 $\mathrm{g} / \mathrm{ml}$. The thirty six (36) rats for the experiment were divided into 6 groups of 6 animals each. After ninety (90) days, 24 of the 30 hyperlipidemic rats were administered with graded doses of the fruit extract. Group I was the negative control and it was given normal feed and distilled water only. Group two was the positive control and it was given normal feed and triton-X with distilled water only and normal feed. Groups 3, 4, 5, and 6 were administered with geometrical doses $(25,50,100$ and $200 \mathrm{mg} / \mathrm{kg}$ ) of the fruit extract intraperitoneally (i.p.) from a stock concentration of $200 \mathrm{mg} / \mathrm{ml}$. After 24, 48 and $72 \mathrm{hrs,}$ respectively of the effect of the extract on the hyperlipidemic rats, the endocrine function tests were determined. Before the rats were fed with triton $-X$, their weights were taken. The weights were subsequently taken after 30,60 and 90 days of triton administration (adapted from Williamson, et al.,1996).

\section{Endocrine function tests}

Two rats from each of the groups were humanely sacrificed after $24 \mathrm{hrs}, 48 \mathrm{hrs}$ and $72 \mathrm{hrs}$ respectively of the effect of the extract on chronic hyperlipidaemic rats by cutting their throat with a sterile blade. Blood was collected into clean, sterile labelled centrifuge tubes without an anticoagulant and centrifuged at a rate of 12,000 revolutions per minute (rpm) for 10 minutes. The clear, yellow serum was then separated from settled cellular elements and subjected to determination of endocrine function tests.

The endocrine function tests estimated from the serum were thyroid hormones (which included 3, 5, 3' triiodothyronine or $\mathrm{T}_{3}, 3,5,3^{\prime}, 5^{\prime}$ tetraiodothyronine or $\mathrm{T}_{4}$, thyroid stimulating hormone, $\mathrm{TSH}$ ) reproductive hormones (which include testosterone and 17ß-oestradiol) and insulin. 
$\mathrm{T}_{3}$ was determined by the Enzyme Link Immunosorbent Assay (Microwell Elisa) using competitive enzyme immunoassay reaction as described by Chopra et al.,(1971b). $\mathrm{T}_{4}$ also called thyroxine was also determined by Enzyme Linked Immunosorbent Assay (Microwell Elisa) method using monoclonal antibodies specific for $\mathrm{T}_{4}$ as described by Chopra et al., (1971a). TSH called thyrotrophin was determined by the enzyme Linked Immunosorbent Assay (Elisa) method for the quantitative determination in serum as described by Hopton and Harrap, (1986); Bravermann (1996); Fisher (1996). The direct imunoenzymatic assay (Elisa method) described by Sood, (2006) was used for the determination of testosterone and that described by Tsang et al., (1980) was used for oestrogen determination. Insulin determination was carried out by the immunoenzymometric assay described by Sood, (2006).

\section{Determination of total cholesterol}

Two rats in each group were humanely sacrificed by cutting the throat with a sterile blade. Blood was collected from the vena cava into clean, labelled centrifuge tubes without anticoagulant after the extract had been allowed to act for 24,48 , $72 \mathrm{hrs}$ respectively. The blood was centrifuged at a rate of 12,000 rotations per minute (rpm) for 10 minutes. The clear, yellow serum was then separated from settled cellular elements. Cholesterol was assayed by Tindar's reaction (Evans and Stein, 1986; NIH, 1990) using commercial kits, from Fortress Diagnostic Ltd, Antrirn.

\section{Statistical analysis \\ Test of significance between control and treatment means were carried out by Analysis of Variance (ANOVA) using Graph Pad Software, (1998).}

\section{RESULTS}

\section{Change in mean body weight of male albino rats (Wistar strain) after being administered orally with Triton-X for 90} days

The effect of triton- $X$ on mean body weight of albino rats fed orally with triton- $X$ is shown in Table 1 . The increase in body weight observed in the rats was statistically significant $(\mathrm{p}<0.05)$ when compared to day zero in all the groups except in Group one. Group one was not administered with triton-X throughout the period of study. Also, there was a significant percentage weight gain $(\mathrm{p}<0.05)$ in the hyperlipidaemic rats (Groups two-six) when compared with Group one which received standard diet and water ad libitum.

\section{Effect on Thyroid Hormones}

The results of the effect of the aqueous fruit extract of Solanum macrocarpum on thyroid hormones are shown in Table 2. The TSH and $\mathrm{T}_{4}$ increased with increase in extract dose. The increase in TSH and $\mathrm{T}_{4}$ were significant $(\mathrm{p}<0.05)$ at $72 \mathrm{hrs}$, whilst there was no change for $\mathrm{T}_{3}(\mathrm{p}>0.05)$ throughout the period of study.

\section{Effect on Testosterone, Oestradiol and Insulin}

The effect of the aqueous fruit extract of Solanum macrocarpum on testosterone, oestradiol and insulin are shown in Table 3. Oestradiol levels increased significantly $(\mathrm{p}<0.05)$ at $24 \mathrm{hrs}$ and $72 \mathrm{hrs}$ when compared to the negative control (Group one), but the levels of the oestradiol level in the negative control (Group one) were however higher than that of the rats not administered the extract (positive control or Group two). The positive control had an oestradiol level of $(15.00 \pm 4.24) \mathrm{pg} / \mathrm{ml}$, $(12.00 \pm 1.49) \mathrm{pg} / \mathrm{ml}$ and $(13.50 \pm 2.54) \mathrm{pg} / \mathrm{ml}$ at $24 \mathrm{hrs}, 48 \mathrm{hrs}$ and $72 \mathrm{hrs}$ respectively whilst the values of the oestradiol in the negative control rats (Group one) are $(36.50 \pm 2.12) \mathrm{pg} / \mathrm{ml},(20.00 \pm 4.24) \mathrm{pg} / \mathrm{ml}$ and $(24.50+2.12) \mathrm{pg} / \mathrm{ml}$ at $24 \mathrm{hrs}, 48$ hrs and 72 hrs respectively.

The increase in the testosterone level with increase in extract dose was significant at $24 \mathrm{hrs}$ and $48 \mathrm{hrs}$ of study (p < 0.05). The testosterone levels of the positive control (Group two) however remained below $0.20 \mathrm{mg} / \mathrm{ml}$ (i.e. very low) throughout the period of study.

Insulin levels increased significantly ( $\mathrm{p}<0.05$ ) at $48 \mathrm{hrs}$ and $72 \mathrm{hrs}$ when compared to the negative control (Group one). The levels of insulin in the negative control (Group one) were higher than that of the rats not administered the extract (positive control or Group two).

\section{Effect of extract on total cholesterol}

The effect of the aqueous fruit extract of Solanum macrocarpum on total cholesterol of hyperlipidaemic rats administered orally with triton- $X$ for 90 days is shown in Table 4 . There was a non-significant $(P>0.05)$ increase in total cholesterol when compared to the positive control with increase in extract dose at 24,48 and $72 \mathrm{hrs}$ respectively. The oral 
administration of triton-X resulted in a rise in serum cholesterol of rats in the positive control group (i.e. those administered only Triton-X).

\section{DISCUSSION}

The increase in mean body weight of the rats after triton- $X$ administration for 90 days was significant $(\mathrm{p}<0.05)$ [Groups two to six], whilst Group one fed with normal diet was not significant ( $p>0.05$ ). The percentage weight gain in the hyperlipidaernic rats (Groups two to six) was significantly high $(\mathrm{p}<0.05)$ when compared to Group one. Excessive weight gain (obesity) has been implicated in hypertension and ischaemic heart disease (Nwanjo et al., 2006). It probably suggests that the triton-X had induced atherosclerosis as atherosclerosis takes three to six months to be induced in rats (Williamson $e t$ al., 1996).

The hyperlipidaenlic rats fed with graded doses of the aqueous fruit extract of $S$. macrocarpurn had significant increase $(p<0.05)$ in the level of the thyroid hormones TSH and $\mathrm{T}_{4}$ at $72 \mathrm{hrs}$ (Table 2). There was no change in $\mathrm{T}_{3}(\mathrm{p}>0.05)$ throughout the period of study. Thyroid hormones increase the expression of LDL receptors on the hepatocytes and increase the activity of lipid-lowering enzymes, resulting in a reduction in LDL (Ness and Lopez, 1995; Ness et al., 1998; Shin and Timothy, 2003; Gali, 2007). Thus, increase in TSH and. $\mathrm{T}_{4}$ levels as demonstrated by the aqueous fruit extract of $S$. macrocarpum on triton- $\mathrm{X}$ induced hyperlipidaernic rats at $72 \mathrm{hrs}$ increased further the activity of these lipid-lowering enzymes, thus resulting in a reduction of LDL which is responsible for hyperlipidaemia. In addition, thyroid hormones also increase the expression of apolipoprotein $\mathrm{A}_{1}$, a major component of HDL (Taylor et al., 1996; Gali, 2007). Since increased thyroid hormones leads to increased HDL, which in turn leads to reduced hyperlipidaemia, then the aqueous fruit extract of $S$. macrocarpum could probably reduce hyperlipidaemia and could thus be beneficial. $\mathrm{T}_{3}$ (the active hormone) is important in hepatic degradation of cholesterol into bile acids by increasing the transcription of rate-limiting enzyme in the process, the cholesterol 7-hydroxyIase (Ness et al.,1990; Pandak et al.,1997; Gali, 2007). However, graded doses of S. macrocarpum aqueous fruit extract led to no change in $\mathrm{T}_{3}$ levels. Nonetheless, the effects of the thyroid hormones (TSH and $\mathrm{T}_{4}$ ) could be beneficial in reducing the onset of atherosclerosis. The TSH of the anterior pituitary controls the thyroid function (Gali, 2007). Generally, thyroid hormones are found at lower levels with a high fat diet (Williamson et al., 1996). It is therefore not surprising that the hyperlipidaemic rats which were not administered the aqueous fruit extract (Group two) had reduced levels of thyroid hormones when compared to the extract-treated rats (Groups three to six). Thyroid hormones stimulate the synthesis, mobilisation and degradation of lipids. They also lower cholesterol level, and for this reason, D-thyroxine is used in the treatment of hyperlipoproteinaemia (Aliu, 2007).

Testosterone has been found at lower levels with a high fat diet (Williamson et al., 1996). Testosterone the dominant androgen found in the adrenal glands, brain, ovary, pituitary, skin, kidney and testes is reduced in male with myocardial infarction (Williamson et al., 1996). Thus the decrease in testosterone observed in the untreated male hyperlipidaemic rats (Group two) in this study agrees with this report. There was a dose-dependent increase $(\mathrm{p}<0.05)$ in the level of testosterone on extract administration at $24 \mathrm{hrs}$ and $48 \mathrm{hrs}$ implying therefore that the hyperlipidaemia might probably have reduced in the rats on administration of the aqueous fruit extract of $S$. macrocarpum.

Oestradiol levels have been shown to be decreased in patients with myocardial infarction (Odutola, 1992; Williamson et al.,1996). On adminis-tration of the aqueous fruit extract of Solanum macrocarpum to the hyperlipidaernic rats, the levels of oestradiol increased correspondingly (p < 0.05) from $25 \mathrm{mg} / \mathrm{kg}$ to $200 \mathrm{mg} / \mathrm{kg}$ dose at $24 \mathrm{hrs}$ and $72 \mathrm{hrs}$ with the highest increase being obtained at $200 \mathrm{mg} / \mathrm{kg}$. The increase in oestradiol implies therefore that the hyperlipidaemia is probably being reduced. The positive control (Group two) i.e. the rats not administered extract, had lower levels of oestradiol when compared to the extract-treated rats (Groups three to six), indicating hyperlipidaemia in the untreated rats. Oestrogens have been shown to decrease LDL-C by only 5-10\%. It is therefore believed that the lipid effect account for only $25-40 \%$ of the reduction in the incidence of coronary heart disease after oestrogen therapy. A possible mechanism may be a direct effect on the vessel wall, improving blood flow and inhibiting the atherogenic mechanism, independent on effect on plasma lipids (ANON 2008). However, data on men suggest that a 35\% reduction in LDC-C is required to achieve a 50\% reduction in cardiovascular disease i.e. coronary atherosclerosis provided that LDC reductions are the sole cause of cardio-protection (ANON, 2008). Apart from maintaining friendly lipid profile, oestrogen changes the vascular tone by increasing nitric oxide production. Nitric oxide activates guanyl cyclase, increasing intravascular levels of cyclic guanosine 3', 5'-monophosphate (cyclic GMP), and thereby produces vasodilation (Hardman and Limbird, 2001; Sodipo, 2007). They reduce myocardial oxygen requirement by decreasing peripheral vascular resistance (PR) or by reducing cardiac output (CO) or by decreasing both PR and CO, as BP= TPR x CO (Katzung, 2004). Oestrogen also stabilizes the endothelial cells. In Australia, the natural oestrogen grazing of grass is implicated in causing vaginal prolapse in ewes and balanoposthitis in wethers. 
Also, oestrogenmimetic compounds (flavonoids) are found in many plants and studies have shown that eating these plant products may produce slight oestrogen effects (Katzung, 2004). Sodipo et al.,(2008a) has shown that the fruit of $S$. macrocarpum contains flavonoids which have also been separated, isolated and purified in the ethanol extract of the plant (Sodipo et al.,2012b). Thus the fruit of this plant may be eaten as a nutrtaceutical in lowering LDL-C which in turn lowers hyperlipidemia. Naturally occurring steroidal oestrogens are subject to first-pass hepatic metabolism and show low bioavailability when administered orally (Aliu, 2007). This study on S. macrocarpum may be expanded further to see if there is any way of isolating oestrogens from the fruit or other parts of the plant if present, so that it can be a ready source of oestrogens, especially in our menopausal women.

Insulin levels have been found to be decreased in patients with myocardial infarction (Williamson et al.,1996). From the present study (Table 3), the extract significantly increased ( $\mathrm{p}<0.05)$ the level of insulin in hyperlipidaemic rats at 48 hrs and $72 \mathrm{hrs}$ and the increase was dose-dependent. In addition to promoting systemic atherosclerosis, dyslipidaemia may also contribute to the development of glomerulosclerosis and therefore chronic renal failure (John, 1991; Mshelia and Gashau, 2007). Furthermore, islet- $\beta$-cell dysfunction caused by lipotoxicity may result in hyperg1ycaemia, which also leads to hyperlipidaemia-vicious cycle (Sjoholm, 1998a; Aliu, 2007; Mshelia and Gashau, 2007). Also the decreased HDL-C found in diabetes mellitus patients are not typically associated with marked increase in plasma total cholesterol and LDL-C (Cabezes et al., 1993; Syvanne and Taskinen, 1997). Also there seems to be few studies relating diabetes to hyperlipidaemia (Sjoholm, 1998a). VLDL contains more triglycerides and less cholesterol, phospholipids and protein. They transport triglycerides from the liver to other tissues for utilization or storage. Triglycerides are removed from VLDL and chylomicrons by lipoproteinlipase. The activity of this enzyme is increased by insulin and thyroxine (Hardman and Limbird, 2001). Thus, by increasing level of insulin at $48 \mathrm{hrs}$ and $72 \mathrm{hrs}$, the aqueous fruit extract of $S$. macrocarpum increases the conversion of VLDL to triglycerides and thus reduces hyperlipidaemia as triglycerides are being utilized. It should be noted that chylomicrons are synthesized from fatty acids of dietary triglycerides and cholesterol absorbed from the small intestine by epithelial cells using the enzyme, diacylglycerol transferase (Hardman and Limbird, 2001). Overproduction of insulin (hyperinsulinaemia) is rare, but increased levels in the blood have been incriminated in bovine ketosis and also in snorter dwarfism of beef cattle (Aliu, 2007).

\section{CONCLUSION}

The aqueous fruit extract of $S$. macrocarpum increased the level of endocrine function indices-thyroid hormones $\left(\mathrm{T}_{3}, \mathrm{~T}_{4}, \mathrm{TSH}\right)$, reproductive hormones (testosterone and $17 \beta$-oestradiol) and insulin, the pancreatic hormone under the conditions of this study, probably contributing to the lipid lowering effect of the plant.

\section{ACKNOWLEDGEMENTS}

The authors gratefully acknowledge the technical assistance of Mr. Fine Akawo of Chemistry Department, University of Maiduguri and Mr. Kolawole Akindoyin (Chief Medical Laboratory Scientist, Chemical Pathology, University of Maiduguri Teaching Hospital) for hormonal analysis. The University of Maiduguri is also appreciated for the Research Grant and Fellowship granted to the first author.

\section{REFERENCES}

1. Aliu YO (2007). Endocrine Pharmacology Veterinary Pharmacology, $1^{\text {st }}$ ed. Tamaza Pub. Co. Ltd Zaria, Nigeria pp. $282-341$.

2. ANON (2008) WO/1996/021443. Use of 3, 4-Diphenyl chromans for the manufacture of a pahrmaceutial composition for the treatment of prophylaxsis of hyperlipoproteinaemia, hypertriglyceridaemia, hyperlipidaemia or hypercholesterolaemia or arteriosclerosis or for anticoagulative treatment. Htrp://www.wipo.int/pctdb/en/wo.jsp?1A=Dk 1996000014 \& DISPLAY = DESC. Access date: 25/11/2008.

3. Anthony PK (2003). Pharmacology Secrets Lanley \& Belfus. Inc. Philadelphia, PA 19107pp. 225 - 235.

4. Bravermann, L.E. (1996). Evaluation of thyroid status in patients with thyrotoxiconsis Clin. Chem. 42: 174 $-181$.

5. Cabezes MC, DeBruin TWA and DeValik HW (1993). Impaired fatty acid metabolism in familial combined hyperlipidaemia: a metabolic associating hepatic apolipoprotein B overproduction and insulin resistance. J. Clin. Invest 16: $160-168$.

6. Chopra IJ. Hershman JM, Pardridge WM and Nicoloff JT (1971a). A radio immune assay of thyroxine. $J$. Clin Endocrinol 33: 865 - 869. 
7. Chopra IJ. Hershman JM, Pardridge WM and Nicoloff JT (1971b). A radio immune assay of triiodothyronine J. Clin. Endocrine. 33: $870-874$.

8. CIOMS (1985): Council of International Organizations of Medical Sessions. International Guiding Principles for Biochemical Research Regarding Animals c\% WHO K2 11. Geneva 27, Switzerland.

9. Davidson NO, Carlos RC and Lukaszewics AM (1998). Apolipoprotein B mRNA editing is modulated by thyroid hormone analogs but not growth hormone administration in rat. Mol. Endocrinol. 4: 779-785.

10. Dillman WH (1990). Biochemical basis of thyroid hormone action in the heart Am. J. Med. 86: 626 - 630.

11. Evans A and Stein MD (1986) Textbook of Clinical Chemistry (Tietz, N-W. ed) WH. Sanders Co. Philadelphia. pp.884-887.

12. Fernando MR. Wickramansingbe, SMD, Nalinle I, Thabrew MI, Ariyanando PT and Karunanayake, EH (1991). Effects of Artocarpus heterophyllus and Aesterachantus longifolia on glucose tolerance in normal subjects and in maturity-onset diabetic patients. J Etnopharmacol. 31:277-283.

13. Fisher DA (1996). Physiological variations in thyroid hormones. Physiological and pathological considerations. Clin. Chem. 42: 135 - 139.

14. Gali RM (2007). Lipid profile in patients with thyroid diseases attending University of Maiduguri Teaching Hospital in North Eastern Nigeria. M.Sc. Dissertation, University of Maiduguri, Maiduguri, Nigeria. 60pp.

15. Graph Pad Software (1998). Graph Pad Software, Inc. San Diego, California, U.S.A. www.graphpad. corn.

16. Grubben GJH and Denton OA (2004). PROTA 2. Plant Resources of Tropical Africa 2 Vegetables. Ponen and Looijen hv, Wagening en, Netherlands. 667pp.

17. Hardman JG and Limbird LE (2001). Drug therapy for hyperlipidaemia and dyslipidaemia. Goodman and Gilmans The pharmacologic Basis of Therapeutics. $10^{\text {th }}$ ed. McGraw - Hill Co. USA pp $971-1001$.

18. Hopton MR and Harrap JJ (1986). Immunoradiometric assay of thyrotropin as a first line thyroid function test in the routine laboratory. Clin. Chem. 32: $691-698$.

19. Jackson IM (1982). Thyrotropin releasing hormone. N. Engl. J. Med. 306: 145 - 155.

20. John FM (1991). Lipids and progressive kidney disease. Kid Intern 39: 355 - 405.

21. Katzung BG (2004). Basic and Clinical Pharmacology. 9th ed. A Lange medical publication. McGraw Hill Co. Singapore. 115lpp.

22. Lin J, Opuku, AR, Gaheeb-Keller M, Hutchings AD, Terbianche SE, Jager AK and Vans-Starden J (1999). Preliminary screening of some traditional Zulu medicinal plants for anti-inflammatory and anti-bacterial activities. J. Ethnopharniacol. 68:267-274.

23. Mittal CC, Aguwa CN, Ezeinu BU and Akubue P1(1981). Preliminary pharmacological studies. on antivenom action of Diodia scandens leaves. Nig, J Pharm. 2: 432-436.

24. Mshelia DS and Gashau W (2007). Characteristics of lipid profiles analysis in public hospital practice in northeastern Nigeria Kanem J. Med. Sci. 1(1): 10-13.

25. Ness GC and Lopez (1995). Transcriptional regulation of rat hepatic low density lipoprotein receptor and cholesterol - 7 - alpha hydroxylase by thyroid hormone. Arc. Biochem. Biophys. 323: $404-408$.

26. Ness GC, Lopez D, Chambers CW, Newsome WP, Cornelius P, Long CA and Harwood HJ Jr. (1998). Effects of L-triiodothyroninine and the L - 94901 on serum lipoprotein levels and hepatic low density lipoprotein receptor, 3 - hydroty - 3- methylglutaryl coenzyme A reductase and apo A - 1 gene expression. Biochem Pharmacol. 6: $121-129$.

27. NIH (1990): National Institute of Health. Recommendations for 'Improving cholesterol measurement. $A$ Report from the Lab Standardization Panel of the National Cholesterol Education Programme. NIH Publication No. 90-2564.

28. Odutola AA (1992). Rapid Interpretation of Routine Clinical Laboratory Tests. J. Asekome and Company, Zaria, p. 112.

29. Oppenheimer JH (1972). Initiation of thyroid hormone action. N. Engl. J. Med. 292: 1063 - 1068.

30. Pandak WM, Heiman DM, Redford K, Stravitz RT, Chiang YJ. Hylemon PB and Vlahcevic ZR (1997). Hormonal regulation of cholesterol $7 \alpha$-hydroxylase specific activity mRNA levels and transcriptional activity in vivo in rat. J. Lipid Res. 38: $2483-2491$.

31. Shin DJ and Timothy FO (2003). Thyroid hormone regulation and cholesterol metabolism are connected through sterol regulatory element - binding protein - 2 (SREBP-2). J. Biol. Chem. 278. 34114 - 34118.

32. Sjoholm A (1998a). Time for more active-lipid-lowering treatment of patients with diabetes. Negative effect of hyperlipidaemia in beta cell is a neglected field. Lakarlidingen 98: 5750 - 5752 .

33. Sjoholm, A (1998b). Aspects of novel sites, of regulation of insulin stimulus - secretion coupling in normal and diabetic pancreatic islets. Endocrine 9: 1-13. 
34. Sodipo OA (2007). Environmental hazards of nitrate / nitrite poisoning. Env. Watch J. 3 (1): $94-102$.

35. Sodipo OA (2009) Studies on chemical components and some pharmacological activities of Solanum macrocarpum Linn. fruit (Garden egg). Ph.D. Thesis, University of Maiduguri, Maiduguri. 387pp.

36. Sodipo OA, Abdulrahman FI, Akan JC and Akinniyi JA (2008a). Phytochemical screening and elemental constituents of the fruit of Solanum macrocarpum Linn. Continental J. Appl. Sci. 3: 88 - 97.

37. Sodipo OA, Abdulrahman FI, Sandabe UK and Akinniyi JA (2008b). Effect of aqueous fruit extract of Solanum macrocarpum Linn on cat blood pressure and rat gastrointestinal tract J. Pharm. Biores. 5(2): 52 59.

38. Sodipo OA, Abdulrahman FI, Sandabe UK and Akinniyi JA (2009a). Effects of the aqueous fruit extract of Solanum macrocarpum Linn. on some haematological indices in albino rats fed with cholesterol - rich diet. Sahel J. Vet. Sci. 8(2): 5 - 12.

39. Sodipo OA, Abdulrahman FI, Sandabe UK and Akinniyi JA (2009b). Effect of Solanum macrocarpum Linn. on biochemical liver function in diet -induced hypercholesterolaemic rats. Nig. Vet. J. 30 (1): 1 - 8.

40. Sodipo OA, Abdulrahman FI, Sandabe UK and Akinniyi JA (2009c). Total lipid profile with aqueous fruit extract of Solanum macrocarpum Linn. in rat J. Pharm Biores. 6(1): 10 - 15.

41. Sodipo OA, Abdulrahman FI, Sandabe UK and Akinniyi JA (2011a). Total lipid profile and faecal cholesterol with aqueous fruit extract of Solanum macrocarpum in triton - induced hyperlipidemic albino rats. J. Medicinal Plants Res. 5(6): 3833 - 3838.

42. Sodipo OA, Abdulrahman FI, Sandabe UK and Akinniyi JA (2011b) Biochemcial liver function with aqueous fruits extract of Solanum macrocarpum Linn in albino rats acutely administered triton-X to induce hyperlipidemia J. Appl. Pharm. Sci. 1(1): 89 - 93.

43. Sodipo OA, Abdulrahman FI and Sandabe UK (2012a). Total lipid profile, faecal cholesterol, very low density lipoprotein cholesterol (VLDL-C), atherogenic index (A.I.) and percent atherosclerosis with aqueous fruit extract of Solanum macrocarpum in chronic triton-induced hyperlipidemic albino rats. Current Res. J. Biolog. Sci. 42 (2): $206-214$

44. Sodipo OA, Abdulrahman FI, Alemika TE and Gulani IA. (2012b) Separation, purification isolation, identification and antimicrobial properties of the ethanol fruit extract of "Gorongo" Solanum macrocarpum L. Int. J. Anal. Pharm Biomed. Sci. 1(1): 30 - 38.

45. Sood R (2006). Textbook of Medical Laboratory Technology. $1^{\text {st }}$ ed. Jaypee Brothers Medical Publishers (p) New Delhi, India. pp. $192-672$.

46. Synanne M and Taskinen MR (1997). Lipids and lipoproteins as coronary risk factor in non - insulin dependent diabetes mellitus. Lancet 350 - S: $205-223$.

47. Taylor AH, Wishark P., Lawless DE, Raymond J and Wong NC (1996). Identification of functional positive and negative thyroid responsiveness elements in the rat apolipoprotein A promoter Biochem 35: $8281-8286$.

48. Tsang BK Armstrong DT and Whitfield JF (1980) Steroid biosynthesis by isolated human ovarian follicular cell in vivo J. Clin Endocrinol Metab. 51: 1407 - 1411.

49. Williamson EM, Okpako DT and Evans FJ (1996). Pharmacological Methods in Phytotherapy Research. Vol. 1. Selection, Preparation and Pharmacological Evaluation of Plant Material. Wiley and Sons, England, 228pp.

50. Wseber KA (1992). Thyrotoxicosis and the heart N. Engl. J. Med. 327: $94-98$. 
IOSR Journal of Pharmacy

Vol. 2, Issue 3, May-June, 2012, pp.464-474

Table 1: Change in mean body weight of male albino rats after being administered with triton-x $(400 \mathrm{mg} / \mathrm{kg})$ for 90 days

\begin{tabular}{cccccc}
\hline \multirow{2}{*}{ Group } & \multicolumn{4}{c}{ Mean body Weight \pm S.D. $(g)$} & \multicolumn{2}{c}{$\begin{array}{c}\text { \% Increase in } \\
\text { Mean Body } \\
\text { Weight }\end{array}$} \\
\cline { 2 - 5 } & 0 & 30 & 60 & 90 & \\
\cline { 2 - 5 } & $110.25 \pm 10.50$ & $112.50 \pm 20.45^{\mathrm{a}}$ & $114.00 \pm 12.51^{\mathrm{a}}$ & $117.20 \pm 15.07^{\mathrm{a}}$ & $6.30 \pm 4.57^{\mathrm{a}}$ \\
\hline One* & $100.20 \pm 26.64^{\mathrm{a}}$ & $135.80 \pm 41.26^{\mathrm{b}}$ & $203.44 \pm 52.97^{\mathrm{b}}$ & $214.20 \pm 58.61^{\mathrm{b}}$ & $113.78 \pm 32.37^{\mathrm{b}}$ \\
Two & $80.00 \pm 17.25^{\mathrm{a}}$ & $110.20 \pm 27.52$ & $163.64 \pm 26.93^{\mathrm{b}}$ & $174.20 \pm 15.06^{\mathrm{b}}$ & $117.75 \pm 2.19^{\mathrm{b}}$ \\
Three & $99.40 \pm 29.19^{\mathrm{a}}$ & $131.40 \pm 41.58^{\mathrm{b}}$ & $184.80 \pm 37.58^{\mathrm{b}}$ & $216.80 \pm 41.05^{\mathrm{b}}$ & $117.30 \pm 11.86 \mathrm{~b}$ \\
Four & $116 / 60 \pm 42.58^{\mathrm{a}}$ & $129.00 \pm 11.92^{\mathrm{b}}$ & $172.78 \pm 17.03^{\mathrm{b}}$ & $194.80 \pm 19.74^{\mathrm{b}}$ & $67.07 \pm 22.84^{\mathrm{b}}$ \\
Five & $95.00 \pm 20.96^{\mathrm{a}}$ & $120.40 \pm 36.65^{\mathrm{b}}$ & $192.18 \pm 34.03^{\mathrm{b}}$ & $211.95 \pm 33.74^{\mathrm{b}}$ & $122.11 \pm 12.78^{\mathrm{b}}$ \\
Six & &
\end{tabular}

Within rows, means with different superscripts are statistically significant $(\mathrm{p}<0.05)$ when compared to day zero $(0)$ using one way analysis of variance (ANOVA).

0 day $=$ before triton- $X$ administration

$\mathrm{n}=6$ rats

Group One* = Rats fed with normal diet and had free access to water throughout the 90 days but not administered triton-X

Table 2: Effect of the aqueous fruit extract of $S$. macrocarpum on thyroid hormones

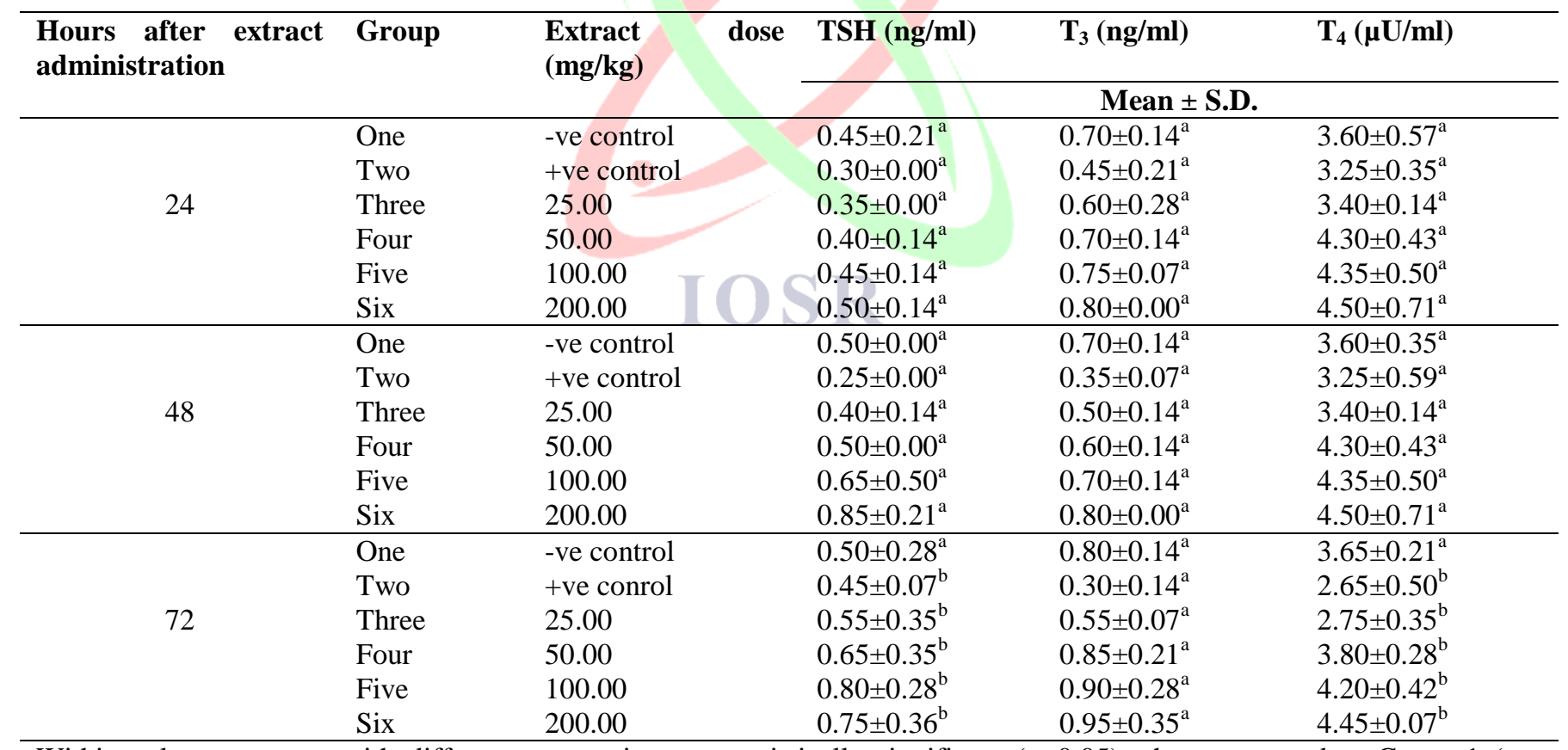

Within columns, means with different superscripts are statistically significant $(\mathrm{p}<0.05)$ when compared to Group 1 (-ve control)

-ve control $=$ Rats fed with normal feed diet and had free access to water

$+v e$ control $=$ Rats fed with normal feed diet and given triton-X 
IOSR Journal of Pharmacy

Vol. 2, Issue 3, May-June, 2012, pp.464-474

Table 3: Effect of the aqueous fruit extract of S. macrocarpum on testosterone oestradiol and insulin

\begin{tabular}{|c|c|c|c|c|c|}
\hline \multirow[t]{2}{*}{$\begin{array}{l}\text { Hours after extract } \\
\text { administration }\end{array}$} & \multirow[t]{2}{*}{ Group } & \multirow[t]{2}{*}{$\begin{array}{l}\text { Extract dose } \\
(\mathrm{mg} / \mathrm{kg})\end{array}$} & $\begin{array}{l}\text { Testosterone } \\
(\mathrm{ng} / \mathrm{ml})\end{array}$ & $\begin{array}{l}\begin{array}{l}\text { Oestradiol } \\
(\mathrm{pg} / \mathrm{ml})\end{array} \\
\end{array}$ & Insulin $(\mu \mathrm{U} / \mathrm{ml})$ \\
\hline & & & \multicolumn{3}{|c|}{ Mean \pm S.D. } \\
\hline \multirow{6}{*}{24} & One & -ve control & $1.50 \pm 0.28^{\mathrm{a}}$ & $36.50 \pm 2.12^{\mathrm{a}}$ & $4.00 \pm 1.41^{\mathrm{a}}$ \\
\hline & Two & +ve control & $<0.20$ & $15.00 \pm 4.24^{\mathrm{b}}$ & $2.00 \pm 0.00^{\mathrm{a}}$ \\
\hline & Three & 25.00 & $<0.20$ & $18.00 \pm 4.24^{\mathrm{b}}$ & $1.20 \pm 0.05^{\mathrm{a}}$ \\
\hline & Four & 50.00 & $0.20 \pm 0.07^{\mathrm{b}}$ & $19.00 \pm 1.41^{\mathrm{b}}$ & $2.00 \pm 0.00^{\mathrm{a}}$ \\
\hline & Five & 100.00 & $0.50 \pm 0.42$ & $20.50 \pm 0.71^{\mathrm{b}}$ & $2.75 \pm 0.35^{\mathrm{a}}$ \\
\hline & Six & 200.00 & $1.05 \pm 0.01^{\mathrm{a}}$ & $25.00 \pm 2.85^{\mathrm{b}}$ & $3.00 \pm 0.00^{\mathrm{a}}$ \\
\hline \multirow{6}{*}{48} & One & -ve control & $1.55 \pm 0.43^{\mathrm{a}}$ & $20.00 \pm 4.24^{\mathrm{a}}$ & $5.00 \pm 0.00^{\mathrm{a}}$ \\
\hline & Two & +ve control & $<0.20$ & $13.00 \pm 1.49^{\mathrm{a}}$ & $2.50 \pm 0.07^{\mathrm{b}}$ \\
\hline & Three & 25.00 & $<0.20$ & $14.00 \pm 4.24^{\mathrm{a}}$ & $1.00 \pm 0.00^{\mathrm{b}}$ \\
\hline & Four & 50.00 & $0.25 \pm 0.35^{\mathrm{b}}$ & $14.50 \pm 2.12^{\mathrm{a}}$ & $2.50 \pm 0.71^{\mathrm{b}}$ \\
\hline & Five & 100.00 & $0.50 \pm 0.42^{\mathrm{b}}$ & $15.50 \pm 0.71^{\mathrm{a}}$ & $3.00 \pm 0.00^{\mathrm{b}}$ \\
\hline & Six & 200.00 & $1.35 \pm 0.21^{\mathrm{b}}$ & $18.00 \pm 2.83^{\mathrm{a}}$ & $4.00 \pm 0.71^{\mathrm{b}}$ \\
\hline \multirow{6}{*}{72} & One & -ve control & $1.60 \pm 0.35^{\mathrm{a}}$ & $24.50 \pm 2.12^{\mathrm{a}}$ & $3.00 \pm 0.00^{\mathrm{a}}$ \\
\hline & Two & +ve control & $<0.20$ & $13.50 \pm 3.54^{\mathrm{b}}$ & $2.05 \pm 0.07^{\mathrm{b}}$ \\
\hline & Three & 25.00 & $<0.20$ & $15.00 \pm 1.41^{\mathrm{b}}$ & $<1.00$ \\
\hline & Four & 50.00 & $<0.20$ & $19.00 \pm 4.24^{\mathrm{b}}$ & $1.00 \pm 0.00^{\mathrm{b}}$ \\
\hline & Five & 100.00 & $0.55 \pm 0.07^{\mathrm{a}}$ & $21.50 \pm 2.12^{\mathrm{b}}$ & $2.15 \pm 0.07^{\mathrm{b}}$ \\
\hline & Six & 200.00 & $1.05 \pm 0.21^{\mathrm{a}}$ & $24.50 \pm 2.12^{\mathrm{b}}$ & $3.00 \pm 0.00^{\mathrm{b}}$ \\
\hline
\end{tabular}

Within columns, means with different superscripts are statistically significant $(\mathrm{p}<0.05)$ when compared to Group 1 (-ve control)

-ve control $=$ Rats fed with normal feed diet and had free access to water

$+\mathrm{ve}$ control $=$ Rats fed with normal feed diet and given triton-X

$<0.20 \mathrm{ng} / \mathrm{ml}=$ Very low for testosterone, $<1.00 \mu \mathrm{UL} / \mathrm{ml}=$ Very low for insulin 
IOSR Journal of Pharmacy

Vol. 2, Issue 3, May-June, 2012, pp.464-474

Table 4: Effect of the aqueous fruit extract of S. macrocarpum on total cholesterol of hyperlipidaemic rats administered orally with triton- $\mathrm{X}$ for 90 days

\begin{tabular}{|c|c|c|c|}
\hline \multirow[t]{2}{*}{$\begin{array}{c}\text { Hours after } \\
\text { extract } \\
\text { Administration }\end{array}$} & \multirow[t]{2}{*}{ Group } & \multirow[t]{2}{*}{ Extract dose (mg/kg) } & \multirow[t]{2}{*}{ Total Cholesterol (mmol/L) } \\
\hline & & & \\
\hline \multirow{6}{*}{24} & One & -ve control & $1.70 \pm 0.28^{\mathrm{a}}$ \\
\hline & Two & +ve control & $2.40 \pm 0.29^{\mathrm{a}}$ \\
\hline & Three & 25.00 & $2.15 \pm 0.64^{\mathrm{a}}$ \\
\hline & Four & 50.00 & $2.10 \pm 0.57^{\mathrm{a}}$ \\
\hline & Five & 100.00 & $1.35 \pm 0.07^{\mathrm{a}}$ \\
\hline & Six & 200.00 & $1.15 \pm 0.07^{\mathrm{a}}$ \\
\hline \multirow{6}{*}{48} & One & -ve control & $1.70 \pm 0.14^{\mathrm{a}}$ \\
\hline & Two & +ve control & $2.55 \pm 0.07^{\mathrm{a}}$ \\
\hline & Three & 25.00 & $2.10 \pm 1.13^{\mathrm{a}}$ \\
\hline & Four & 50.00 & $1.50 \pm 0.14^{\mathrm{a}}$ \\
\hline & Five & 100.00 & $1.45 \pm 0.07^{\mathrm{a}}$ \\
\hline & Six & 200.00 & $1.25 \pm 0.35^{\mathrm{a}}$ \\
\hline \multirow{6}{*}{72} & One & -ve control & $1.90 \pm 0.14^{\mathrm{a}}$ \\
\hline & Two & +ve control & $2.40 \pm 0.50^{\mathrm{a}}$ \\
\hline & Three & 25.00 & $2.20 \pm 0.28^{\mathrm{a}}$ \\
\hline & Four & 50.00 & $2.10 \pm 0.42^{\mathrm{a}}$ \\
\hline & Five & 100.00 & $1.70 \pm 0.14^{\mathrm{a}}$ \\
\hline & Six & 200.00 & $1.35 \pm 0.07^{\mathrm{a}}$ \\
\hline
\end{tabular}

Within columns, means with the same superscript are not statistically significant (p>0.05) when compared to Group 1 (-ve control)

-ve control = Rats fed with normal feed diet and had free access to water

$+\mathrm{ve}$ control $=$ Rats fed with normal feed diet and given triton-X 